\section{ARTE E SAÚDE: UMA INTERFACE A SERVIÇO DA INTEGRALIDADE}

\section{ART AND HEALTH: AN INTERFACE AT THE SERVICE OF INTEGRALITY}

\section{RESUMO}

O presente trabalho tem como objetivo explorar as práticas de arte em saúde e sua possível relação com a Integralidade. Foram utilizadas quatro distintas abordagens dessa interface, que foram escolhidas a fim de ressaltar a pluralidade deste tema e também por serem práticas com maior impacto social, são elas: arteterapia junguiana, arteterapia gestáltica, doutores da alegria e práticas de arte em terapia ocupacional. Para isso foi realizada uma pesquisa qualitativa exploratória por meio de investigação documental realizada nos principais documentos destas abordagens. Os resultados constatam que essas abordagens amparam os seguintes preceitos: (1) ética de cuidado em saúde; (2) autonomia e emancipação - marco conceitual da promoção da saúde; (3) prevenção, tratamento e reabilitação; (4) luta social no enfrentamento de modelos hegemônicos em saúde, criando espaços para a inclusão social. Tais preceitos encontrados nestas práticas são coerentes com os princípios da noção de Integralidade. Através deste estudo conclui-se que as práticas de arte são ferramentas valiosas para a implementação da Integralidade.

\section{PALAVRAS-CHAVE}

Interface Arte e Saúde.

Práticas de arte em saúde.

Integralidade.

Cuidado.
Joana Anschau Roman - Programa de Pós-Graduação em Saúde Coletiva da Universidade Federal de Santa Catarina. Conclusão Janeiro 2014.

CORRESPONDENTE

Joana Anschau Roman joanaroman@gmail.com

Marco Aurélio D’Ros ros@univali.br 


\begin{abstract}
This paper aims to explore the art practices in health and the possible relation with Integrality. The research used four distinct approaches that interface, were chosen in order to emphasize the plurality of this topic and also because they are practice with greater social impact, they are: Jungian art therapy, gestalt art therapy, doctors of joy and art practices in occupational therapy. For that we conducted a qualitative exploratory study using documentary research performed in the main documents of these approaches. The results conclude that the approaches bolster the following precepts: (1) ethics of health care; (2) autonomy and emancipation conceptual framework of health promotion; (3) prevention, treatment and rehabilitation; (4) social struggle in confronting the hegemonic models in health, creating spaces for social inclusion. Such precepts found in these practices are consistent with the principles of the notion of Integrality. Through this study it is concluded that art practices are valuable tools for the implementation of Integrality.
\end{abstract}

KEYWORDS: Art and Health interface. Art practices in health. Integrality. Care. 